\title{
Efektivitas Pemberian Terapi Cairan Inisial Dibandingkan Terapi Cairan Standar WHO terhadap Lama Perawatan pada Pasien Demam Berdarah di Bangsal Anak Rumah Sakit PKU Muhammadiyah Bantul
}

\author{
Asnia Rahmawati ${ }^{1,4}$, Dyah A. Perwitasari ${ }^{1}$, Nurcholid U. Kurniawan ${ }^{2,3}$ \\ ${ }^{1}$ Program Studi Magister Farmasi, Universitas Ahmad Dahlan, Yogyakarta, Indonesia, \\ ${ }^{2}$ Staf Bagian Ilmu Kesehatan Anak, Fakultas Kedokteran, Universitas Ahmad Dahlan, \\ Yogyakarta, Indonesia, ${ }^{3} \mathrm{KSM}$ Ilmu Kesehatan Anak RS PKU Muhammadiyah \\ Bantul, Yogyakarta, Indonesia, ${ }^{4}$ UPTD Puskesmas Tamalanrea, Makassar, Indonesia
}

\begin{abstract}
Abstrak
Demam berdarah dengue (DBD) merupakan penyakit infeksi yang disebabkan oleh virus dengue. Kasus DBD di Kabupaten Bantul pada tahun 2016 berjumlah 1.706 dengan 13 kematian. Salah satu kunci keberhasilan terapi pada pasien DBD adalah menjaga tercukupinya kebutuhan cairan pasien selama fase kritis. Penelitian ini bertujuan untuk mengetahui perbedaan pemberian terapi cairan inisial terhadap perbaikan klinis, laboratoris dan lama rawat inap dibandingkan terapi standar WHO pada pasien dengue fever (DF) dan dengue hemorrhagic fever (DHF) di bangsal anak RS PKU Muhammadiyah Bantul. Penelitian ini dilakukan di bangsal anak RS PKU Muhammadiyah Bantul pada bulan Februari sampai dengan Juni tahun 2018 menggunakan metode eksperimental single blind randomised clinical trial pada dua kelompok yaitu cairan standar WHO $(n=24)$ dan cairan inisial $(n=24)$. Hasil yang diukur yaitu luaran terapi suhu badan, hematokrit, trombosit dan lama rawat inap. Perbedaan antarkelompok dianalisis dengan unpaired t-test dan Mann-Whitney. Berdasarkan hasil penelitian, kedua kelompok tidak menunjukkan perbedaan bermakna terhadap rata-rata suhu badan dan hematokrit $(p>0,05)$, sedangkan kedua kelompok menunjukkan perbedaan yang bermakna terhadap rata-rata peningkatan trombosit dan lama rawat inap $(\mathrm{p}<0,05)$. Hal ini menunjukkan bahwa kelompok cairan inisial memiliki rata-rata

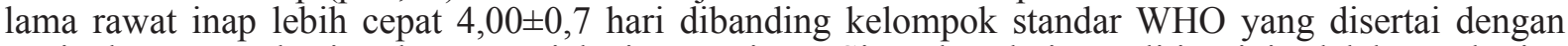
peningkatan trombosit selama menjalani rawat inap. Simpulan dari penelitian ini adalah pemberian terapi cairan inisial tidak memberikan perbedaan yang signifikan terhadap rata-rata suhu badan dan hematokrit, sedangkan efektivitas antara kedua kelompok menunjukkan perbedaan yang bermakna terhadap rata-rata peningkatan trombosit dan lama rawat inap.
\end{abstract}

Kata kunci: Cairan inisial, demam berdarah dengue, hematokrit, lama rawat inap, suhu badan, trombosit

\section{Effectiveness of Initial Fluid Therapy Compared to WHO Standard Therapy on the Length of Stay of Patients with Dengue Fever in Children's Ward PKU Muhammadiyah Bantul Hospital}

\begin{abstract}
Dengue hemorrhagic fever (DHF) is an infectious disease caused by the dengue virus. The number of dengue cases in Bantul Regency in 2016 was 1,706 with 13 deaths. One of the keys to successful therapy in DHF patients is to maintain adequate fluid requirements for patients during the critical phase. This study aimed to determine differences in initial fluid therapy for clinical, laboratory improvement and length of stay compared to WHO standard therapy in dengue fever (DF) and DHF patients in pediatric ward PKU Muhammadiyah Bantul Hospital, Yogyakarta, Indonesia. This research was conducted in the pediatric ward of PKU Muhammadiyah Bantul Hospital in February 2018 to June 2018 using a single blind randomized clinical trial experimental method. Samples were divided into two groups, namely WHO standard fluid $(n=24)$ and initial fluid $(n=24)$. The results measured were body temperature, hematocrit, platelets and length of stay. Differences between groups were analyzed using unpaired t-test and Mann-Whitney. The two groups showed a significant difference toward the increase in platelets and length of stay $(p<0.05)$. This suggests that the initial fluid group had an average length of stay $4.00 \pm 0.7$ days faster than the WHO standard group which was accompanied by an increase in platelets during hospitalization. In conclusion, the initial fluid therapy did not give a significant difference to the mean body temperature and hematocrit, while the effectiveness between the two groups showed a significant difference toward the increase in platelets and length of stay.
\end{abstract}

Keywords: Body temperature, dengue hemorrhagic fever, hematocrit, initial fluid, length of stay, platelets

Korespondensi: Asnia Rahmawati, S.Farm., Apt, Program Studi Magister Farmasi, Universitas Ahmad Dahlan, Yogyakarta, D.I. Yogyakarta 55164, Indonesia, email: asnia.rahmawati91@gmail.com

Naskah diterima: 11 September 2018, Diterima untuk diterbitkan: 17 April 2019, Diterbitkan: 28 Juni 2019 


\section{Pendahuluan}

Infeksi dengue merupakan sebuah penyakit menular yang menjangkit manusia dan banyak ditemukan di daerah tropis dan subtropis. Infeksi dengue ditularkan melalui nyamuk, khususnya jenis Aedes aegypti dan Aedes albopictus. ${ }^{1}$ Berdasarkan data yang diperoleh dari World Health Organization (WHO) pada tahun 1968 sampai dengan 2009, Indonesia merupakan salah satu negara di kawasan Asia Tenggara yang tercatat dengan angka kejadian DBD tertinggi. Angka kejadian DBD tersebut tercatat di 34 provinsi di Indonesia, yakni sebanyak 100.347 pasien DBD pada tahun 2014, yang di antaranya terdapat 907 pasien yang tidak dapat tertolong, sedangkan pada tahun 2015 terdapat peningkatan kejadian DBD menjadi 126.675 pasien dengan 1.229 pasien di antaranya meninggal dunia. ${ }^{2}$

Pada kasus DBD, untuk menurunkan angka morbiditas dan mortilitas, dibutuhkan pengobatan yang optimal. Salah satu terapi yang perlu diperhatikan adalah pemberian terapi cairan baik dari segi jenis, jumlah, serta kecepatan cairan untuk mencegah terjadinya perembesan plasma yang umumnya terjadi pada fase penurunan suhu di hari ke-3-6. ${ }^{3}$ Terjadinya kehilangan cairan pada ruang intravaskular dapat diatasi dengan pemberian salah satu jenis cairan seperti kristaloid (ringer laktat, ringer asetat, cairan salin) ataupun koloid. ${ }^{4}$ Penelitian uji klinis terkait pemberian cairan baik dari segi jumlah ataupun kecepatan masih sangat sedikit diperoleh.

Meskipun demikian, pemberian cairan yang cukup diharapkan mampu mengatasi kebocoran plasma yang terjadi pada ruang intravaskular. Menurut Chen et al. (2009), pada umumnya proses kebocoran plasma dan trombositopenia terjadi antara hari keempat hingga keenam sejak demam berlangsung. ${ }^{3}$ Selanjutnya, proses kebocoran plasma akan berkurang dan cairan akan kembali dari ruang interstitial ke intravaskular di hari ketujuh.
Oleh karena itu, interpretasi yang cermat dan penilaian pada data klinis dan laboratoris untuk manajemen kebutuhan cairan pasien DBD sangat penting untuk dilakukan. Tujuan dari penelitian ini adalah untuk mengetahui perbedaan pemberian terapi cairan inisial terhadap perbaikan klinis, laboratoris dan lama rawat inap dibandingkan terapi standar WHO pada pasien dengue fever (DF) dan dengue hemorrhagic fever (DHF) di bangsal anak Rumah Sakit PKU Muhammadiyah Bantul, Yogyakarta. Penelitian ini dapat menjadi masukan dalam menunjang pengobatan terkait pemberian terapi cairan inisial yang dapat digunakan dalam tatalaksana pasien DBD.

\section{Metode}

Penelitian ini dilakukan dengan menggunakan desain penelitian eksperimental single blind randomised clinical trial. Variabel penelitian terdiri dari variabel bebas (terapi cairan standar WHO dan cairan inisial) dan variabel terikat (pemeriksaan suhu badan, hematokrit, trombosit dan lama rawat inap). Adapun jenis cairan yang diberikan untuk kristaloid berupa ringer laktat, sedangkan untuk koloid berupa gelofusal, dan pemberian salah satu jenis cairannya disesuaikan dengan prosedur terapi cairan berdasarkan diagnosis dokter penanggungjawab terkait derajat keparahan demam berdarah pasien. Data pasien yang diperoleh merupakan data pasien yang berobat pada bulan Februari-Juni 2018 di bangsal anak RS PKU Muhammadiyah Bantul.

Populasi dalam penelitian ini adalah pasien anak berusia 1 bulan sampai 18 tahun yang menderita DF (ICD-10: A90) dan DHF (ICD10: A91) di RS PKU Muhammadiyah Bantul. Sampel penelitian ini adalah seluruh pasien dengan DBD yang memenuhi kriteria inklusi dan eksklusi. Kriteria inklusi adalah pasien perempuan dan laki-laki usia 1 bulan sampai 18 tahun, pasien yang mendapat perawatan di IGD dan bangsal anak minimal 1 hari, data 
laboratorium yang lengkap (trombosit dan hematokrit) tiap 24 jam, dan wali pasien bersedia mengisi informed consent. Kriteria eksklusi meliputi pasien rujukan dari rumah sakit lain yang telah mendapatkan terapi cairan awal DBD dan pasien yang mendapat rujukan ke tingkat rumah sakit yang lebih tinggi. Penelitian ini telah mendapatkan persetujuan kelaikan etik (ethical clearance) dari Komisi Etik Penelitian Kesehatan RSUD Dr. Moewardi dengan nomor 62/II/HREC/ 2018, izin penelitian dari Direktur Utama RS PKU Muhammadiyah Bantul beserta izin wali pasien (informed consent).

Pengambilan data dilakukan pada pasien yang telah mendapatkan terapi cairan standar WHO (6-7 mL/kgBB/jam) dan cairan inisial (10 mL/kgBB/15 menit). Pengukuran suhu badan dilakukan pada saat pasien masuk rumah sakit dan pengukuran suhu selanjutnya dilakukan minimal setiap 8 jam/hari selama menjalani perawatan, sedangkan pengukuran hematokrit dan trombosit dilakukan pada saat pasien masuk rumah sakit dan pengukuran selanjutnya dilakukan setiap 24 jam selama menjalani perawatan. Pengukuran lama rawat inap dihitung berdasarkan hari saat pasien mulai diberikan cairan inisial/standar WHO hingga dinyatakan sembuh dan dibolehkan pulang oleh dokter penanggung jawab pasien.

\section{Hasil}

Karakteristik pasien yang menerima terapi cairan tersebut dapat dilihat pada Tabel 1 . Diketahui bahwa perbandingan jenis kelamin pasien laki-laki dengan perempuan adalah 1:1. Pasien laki-laki mendominasi sebesar $66,7 \%$ pada penggunaan terapi cairan inisial sedangkan pasien perempuan mendominasi sebesar $66,7 \%$ pada penggunaan terapi cairan standar WHO $(\mathrm{p}=0,021)$. Sebesar $62,5 \%$ pasien didominasi oleh kelompok usia 0-60 bulan, sedangkan sisanya didominasi oleh kelompok usia $72-132$ bulan yakni sebesar $29,2 \%$ dan kelompok usia 144-216 bulan sebesar 8,3\% dengan mean \pm SD $64,38 \pm 45,547$ bulan. Pada penelitian ini, terdapat perbedaan usia pada antarkelompok $(\mathrm{p}=0,005)$. Data karakteristik pasien lainnya terdapat pada Tabel 1 . Seluruh variabel tidak menunjukkan perbedaan antar kelompok $(\mathrm{p}>0,05)$. Tidak adanya perbedaan antarkelompok menunjukkan adanya kemiripan karakteristik pasien penelitian yang tinggi.

Tabel 1 Karakteristik Pasien Dengue Fever (DF)/Dengue Hemorrhagic Fever (DHF)

\begin{tabular}{|c|c|c|c|c|c|}
\hline \multirow{2}{*}{ Karakteristik } & \multirow{2}{*}{ Keterangan } & \multirow{2}{*}{$\begin{array}{c}\text { Jumlah Total } \\
\text { n (\%) }\end{array}$} & \multirow{2}{*}{$\begin{array}{c}\text { Standar WHO } \\
\mathrm{n}(\%)\end{array}$} & \multirow{2}{*}{$\begin{array}{c}\text { Cairan Inisial } \\
\text { n (\%) }\end{array}$} & \multirow[t]{2}{*}{ Nilai $p$} \\
\hline & & & & & \\
\hline \multirow[t]{2}{*}{ Jenis kelamin } & Laki-laki & $24(50,0)$ & $8(33,3)$ & $16(66,7)$ & \multirow{2}{*}{$0,021 \mathrm{a} *$} \\
\hline & Perempuan & $24(50,0)$ & $18(66,7)$ & $8(33,3)$ & \\
\hline \multirow[t]{4}{*}{ Usia (bulan) } & $0-60$ & $30(62,5)$ & $12(40)$ & $18(60,0)$ & \multirow{3}{*}{$0,005 b^{*}$} \\
\hline & $72-132$ & $14(29,2)$ & $8(57,1)$ & $6(42,9)$ & \\
\hline & $144-216$ & $4(8,3)$ & $4(100,0)$ & $0(0,0)$ & \\
\hline & Mean \pm SD (bulan) & $64,38 \pm 45,547$ & $82,50 \pm 48,934$ & $46,25 \pm 34,045$ & - \\
\hline Suhu awal & Mean $\pm \mathrm{SD}\left({ }^{\circ} \mathrm{C}\right)$ & - & $37,57 \pm 1,15$ & $37,04 \pm 0,65$ & $0,054^{\mathrm{b}}$ \\
\hline \multirow[t]{2}{*}{ Penyakit penyerta } & Ada & $20(41,7)$ & $9(37,5)$ & $11(45,8)$ & \multirow{2}{*}{$0,558^{\mathrm{a}}$} \\
\hline & Tidak ada & $28(58,3)$ & $15(62,5)$ & $13(54,2)$ & \\
\hline \multirow[t]{2}{*}{ Antipiretik } & Tidak ada & $20(41,7)$ & $9(37,5)$ & $11(45,8)$ & \multirow{2}{*}{$0,558^{\mathrm{a}}$} \\
\hline & Ada (IV) & $28(58,3)$ & $15(62,5)$ & $13(54,2)$ & \\
\hline \multirow[t]{2}{*}{ Diagnosis penyakit } & DF & $38(79,2)$ & $18(75)$ & $20(83,3)$ & \multirow{2}{*}{$0,477^{\mathrm{a}}$} \\
\hline & DHF & $10(20,8)$ & $6(25)$ & $4(16,7)$ & \\
\hline
\end{tabular}


Tabel 2 Efektivitas Terapi Cairan terhadap Luaran Terapi Suhu Badan

\begin{tabular}{|c|c|c|c|}
\hline \multirow[b]{2}{*}{ Hari Demam } & \multicolumn{2}{|c|}{ Suhu Badan } & \multirow[b]{2}{*}{ Nilai p } \\
\hline & $\begin{array}{c}\text { Standar WHO } \\
(n=24)\end{array}$ & $\begin{array}{c}\text { Cairan Inisial } \\
(\mathrm{n}=24)\end{array}$ & \\
\hline Demam hari ke-4 & & & \\
\hline $\begin{array}{l}\text { Mean } \pm \text { SD } \\
\mathrm{n}(\%)\end{array}$ & $\begin{array}{c}37,4 \pm 0,8 \\
24(100,0)\end{array}$ & $\begin{array}{c}37,2 \pm 0,5 \\
24(100,0)\end{array}$ & $0,258^{\mathrm{a}}$ \\
\hline $\begin{array}{l}\text { Demam hari ke-5 } \\
\text { Mean } \pm \text { SD } \\
\text { n }(\%)\end{array}$ & $\begin{array}{c}37,0 \pm 0,5 \\
24(100,0)\end{array}$ & $\begin{array}{c}36,8 \pm 0,3 \\
24(100,0)\end{array}$ & $0,134^{b}$ \\
\hline $\begin{array}{l}\text { Demam hari ke-6 } \\
\text { Mean } \pm \text { SD } \\
\mathrm{n}(\%)\end{array}$ & $\begin{array}{c}36,7 \pm 0,4 \\
24(100,0)\end{array}$ & $\begin{array}{c}36,8 \pm 0,4 \\
24(100,0)\end{array}$ & $0,605^{\mathrm{b}}$ \\
\hline $\begin{array}{l}\text { Demam hari ke-7 } \\
\text { Mean } \pm \mathrm{SD} \\
\mathrm{n}(\%)\end{array}$ & $\begin{array}{l}36,7 \pm 0,5 \\
21(87,5)\end{array}$ & $\begin{array}{l}36,7 \pm 0,2 \\
19(79,2)\end{array}$ & $0,594^{b}$ \\
\hline $\begin{array}{l}\text { Demam hari ke-8 } \\
\text { Mean } \pm \text { SD } \\
\text { n }(\%)\end{array}$ & $\begin{array}{l}36,8 \pm 0,6 \\
13(54,2)\end{array}$ & $\begin{array}{c}36,6 \pm 0,2 \\
5(20,8)\end{array}$ & $0,462^{\mathrm{a}}$ \\
\hline
\end{tabular}

Berdasarkan Tabel 2, hasil uji unpaired t-test dan Mann-Whitney menunjukkan nilai $\mathrm{p}>0,05$, yang artinya secara statistik tidak ada perbedaan yang bermakna antara penggunaan terapi cairan standar WHO dan cairan inisial terhadap suhu badan. Menurut teori, pada fase kritis, terutama hari ke-5 demam, suhu badan akan mengalami penurunan sekitar $\leq 37,5{ }^{\circ} \mathrm{C} .{ }^{1}$ Pada penelitian ini, data yang diambil yakni rata-rata suhu badan pasien di hari ke-5 demam, dan diketahui bahwa suhu pasien yang menggunakan cairan standar WHO berkisar $37,0{ }^{\circ} \mathrm{C}$, sedangkan yang menggunakan cairan inisial berkisar $36,8^{\circ} \mathrm{C}$.

Berdasarkan Tabel 3, hasil uji unpaired $t$-test menunjukkan nilai $\mathrm{p}>0,05$, yang artinya secara statistik tidak terdapat perbedaan bermakna antara penggunaan terapi cairan standar WHO dan cairan inisial terhadap hematokrit. Berdasarkan teori, fase kritis DBD, yaitu periode kebocoran plasma dimulai saat transisi dari fase febris ke fase afebris yang ditandai dengan peningkatan hematokrit, terjadi pada hari ke-3-6. Pengambilan data dilakukan pada fase kritis (terutama hari ke3-6 demam), dan diperoleh nilai hematokrit pada pasien penelitian ini rata-rata $37,7 \%$. Nilai hematokrit minimal yang menggunakan cairan standar WHO yaitu $28 \%$ dan hematokrit maksimal $46,6 \%$, sedangkan pada pasien yang mendapat terapi cairan inisial, nilai hematokrit minimal dan maksimal sebesar $31,9 \%$ dan $41,8 \%$.

Trombositopenia merupakan salah satu kriteria penting yang digunakan sebagai indikator potensial tingkat keparahan klinis DBD. Trombositopenia merupakan kondisi yang menggambarkan penurunan trombosit. Kadar trombosit sebesar $<50.000 / \mathrm{mm}^{3}$ disebut trombositopenia berat, sedangkan 50.000$100.000 / \mathrm{mm}^{3}$ disebut trombositopenia sedang. ${ }^{5}$ Pada penderita DBD, jumlah trombosit sebesar $\leq 100.000 / \mu \mathrm{L}$ umumnya ditemukan pada hari ke-3 sampai ke-7. ${ }^{6}$

Hasil dari uji unpaired t-test menunjukkan nilai $p<0,05$, artinya secara statistik terdapat perbedaan yang bermakna antara penggunaan terapi cairan standar WHO dan cairan inisial terhadap peningkatan trombosit setiap pengukuran 24 jam (Tabel 3). Hal tersebut didukung oleh perbedaan rata-rata trombosit pada demam hari ke-5, sebesar 34,21x103/ $\mu \mathrm{L}$, 
Tabel 3 Efektivitas Terapi Cairan terhadap Luaran Terapi Hematokrit dan Trombosit

\begin{tabular}{|c|c|c|c|c|c|c|}
\hline \multirow{3}{*}{ Hari Demam } & \multicolumn{3}{|c|}{ Hematokrit } & \multicolumn{3}{|c|}{ Trombosit } \\
\hline & $\begin{array}{c}\text { Standar } \\
\text { WHO }\end{array}$ & $\begin{array}{l}\text { Cairan } \\
\text { Inisial }\end{array}$ & Nilai p & $\begin{array}{c}\text { Standar } \\
\text { WHO }\end{array}$ & $\begin{array}{c}\text { Cairan } \\
\text { Inisial }\end{array}$ & Nilai $p$ \\
\hline & $(n=24)$ & $(n=24)$ & & $(n=24)$ & $(n=24)$ & \\
\hline \multicolumn{7}{|l|}{ Demam hari ke-4 } \\
\hline Mean $\pm \mathrm{SD}$ & $37,7 \pm 4,8$ & $37,0 \pm 3,0$ & $0,560^{\mathrm{a}}$ & $135,9 \pm 45,4$ & $159,7 \pm 32,4$ & $0,004^{a *}$ \\
\hline $\mathrm{n}(\%)$ & $24(100,0)$ & $24(100,0)$ & & $24(100,0)$ & $24(100,0)$ & \\
\hline \multicolumn{7}{|l|}{ Demam hari ke-5 } \\
\hline Mean $\pm \mathrm{SD}$ & $37,0 \pm 4,2$ & $35,1 \pm 2,4$ & $0,060^{\mathrm{a}}$ & $114,8 \pm 45,6$ & $149,0 \pm 37,9$ & $0,007^{a *}$ \\
\hline n $(\%)$ & $24(100,0)$ & $24(100,0)$ & & $24(100,0)$ & $24(100,0)$ & \\
\hline \multicolumn{7}{|l|}{ Demam hari ke-6 } \\
\hline Mean $\pm \mathrm{SD}$ & $37,0 \pm 4,3$ & $35,0 \pm 2,6$ & $0,055^{\mathrm{a}}$ & $113,5 \pm 45,4$ & $154,4 \pm 32,4$ & $0,009^{a *}$ \\
\hline n $(\%)$ & $24(100,0)$ & $23(95,8)$ & & $24(100,0)$ & $23(95,8)$ & \\
\hline \multicolumn{7}{|l|}{ Demam hari ke-7 } \\
\hline Mean $\pm \mathrm{SD}$ & $36,1 \pm 4,9$ & $37,5 \pm 3,4$ & $0,403^{\mathrm{a}}$ & $108,0 \pm 56,7$ & $157,0 \pm 38,6$ & $0,012^{\mathrm{a} *}$ \\
\hline n $(\%)$ & $17(70,8)$ & $13(54,2)$ & & $17(70,8)$ & $13(54,2)$ & \\
\hline \multicolumn{7}{|l|}{ Demam hari ke-8 } \\
\hline Mean $\pm \mathrm{SD}$ & $35,5 \pm 4,6$ & $38,3 \pm 4,9$ & $0,361^{\mathrm{a}}$ & $98,3 \pm 60,4$ & $183,3 \pm 37,5$ & $0,039^{a *}$ \\
\hline n $(\%)$ & $12(50,0)$ & $3(12,5)$ & & $12(50,0)$ & $3(12,5)$ & \\
\hline
\end{tabular}

menunjukkan bahwa trombosit penggunaan terapi cairan inisial meningkat lebih cepat setelah melewati 48-72 jam dari masa kritis, yakni perbedaan rata-rata trombosit demam hari ke-8 sebesar 49,00x103/ $\mu \mathrm{L}$.

Berdasarkan Tabel 4, dapat diketahui bahwa analisis uji unpaired t-test bernilai $\mathrm{p}=0,004$, yang secara statistik menunjukkan terdapat perbedaan yang bermakna antara penggunaan terapi cairan standar WHO dibandingkan cairan inisial terhadap hasil lama rawat inap pasien DF/DHF. Hasil mean \pm SD menunjukkan bahwa lama perawatan di rumah sakit pasien yang diberikan cairan inisial lebih cepat 4 hari dengan simpang baku 0,7 , sedangkan pasien yang diberikan terapi cairan standar WHO memiliki lama rawat inap selama 4,96 hari dengan simpang baku 1,4.

\section{Pembahasan}

Hasil penelitian yang diperoleh mengenai gambaran subjek terhadap jenis kelamin pada kedua kelompok baik laki-laki atau perempuan menunjukkan perbandingan yang tidak jauh berbeda. Hasil tersebut menunjukkan bahwa suatu faktor risiko terjadinya infeksi bukanlah disebabkan oleh jenis kelamin. Hal ini didukung hasil penelitian Zumaroh et al. (2015) yang menyatakan perbandingan anak lelaki yang terkena DBD tidak jauh berbeda dengan anak perempuan, yakni 1,2:1.7

Hasil penelitian Kulkarni et al. (2010) di India menunjukkan bahwa pasien yang paling banyak dirawat akibat virus dengue adalah pasien kelompok usia 6-12 tahun. ${ }^{8}$ Hal ini diperkuat dengan hasil penelitian

Tabel 4 Efektivitas Terapi Cairan Terhadap Luaran Terapi Lama Rawat Inap

\begin{tabular}{|c|c|c|c|}
\hline \multirow{2}{*}{ Kelompok } & \multicolumn{2}{|c|}{ Lama Rawat Inap } & \multirow{2}{*}{ Nilai $p$} \\
\hline & $\mathbf{n}$ & $\operatorname{Mean} \pm \mathrm{SD}$ & \\
\hline Standar WHO & 24 & $4,96 \pm 1,4$ & $0,004^{\mathrm{a} *}$ \\
\hline Cairan Inisial & 24 & $4,00 \pm 0,7$ & \\
\hline
\end{tabular}


yang dilakukan Setiawati (2011) di RSUP Persahabatan dan RSUD Budhi Asih Jakarta yang menyatakan bahwa usia yang rentan terinfeksi DBD terbanyak adalah anak usia sekolah, yakni berjumlah 39 anak (65\%). ${ }^{6}$ Menurut Syahribulan et al. (2012), untuk mendapatkan protein yang dibutuhkan dalam proses pematangan telur melalui darah yang dihisap dari host, nyamuk betina Aedes akan aktif terbang pada saat anak-anak biasanya beraktivitas di luar rumah, yakni pagi hari antara pukul 08.00-12.00 WIB dan sore hari pukul 15.00-17.00 WIB. ${ }^{9,10}$

Pada hasil penelitian ini, rata-rata keluarga pasien DF/DHF akan membawa anaknya ke rumah sakit setelah menjalani pengobatan sendiri atau ke dokter pribadi minimal pada hari ke-3 demam dan maksimal pada hari ke-5 demam. Hal ini didukung dengan hasil penelitian Nugraha dan Widijatmoko (2010) bahwa pengambilan sampel darah paling banyak dilakukan pada hari ke-4 demam, yakni sebanyak $26,92 \% .{ }^{11}$ Terapi pengobatan pasien DBD pada dasarnya terdiri atas dua jenis, yakni terapi suportif dan simptomatik. Pengobatan dengan pemberian terapi cairan pengganti, contohnya cairan intravena, disebut sebagai terapi suportif, sedangkan pemberian terapi antipiretik, misal parasetamol, dikenal dengan terapi simptomatik. ${ }^{3}$

Demam yang terjadi pada kasus infeksi dengue dikenal dengan istilah pelana kuda. Ketika awal sakit, pasien mengalami demam tinggi akibat viremia selama 2 hari, kemudian akan terjadi penurunan suhu tubuh yang biasanya terjadi pada demam hari ke- 4 dan ke-5 yang disebut sebagai fase kritis. Fase ini disebabkan oleh replikasi virus sehingga tubuh menjadi terhindar dari respon imun. Sitokin yang dihasilkan menjadi berkurang dan selanjutnya akan bertambah kembali jika proses replikasi tersebut telah selesai. Pada hari ke-6 demam, virus dengue akan siap dikeluarkan melalui proses lisis sel dan suhu tubuh akan meningkat kembali, namun tidak tinggi seperti ketika awal infeksi, sebab tubuh telah membentuk antibodi spesifik sehingga tubuh mampu mengatasi virus tersebut. Akan tetapi, jika fase kritis tidak dapat teratasi, terjadi syok yang ditandai dengan penurunan suhu badan di bawah normal sehingga tubuh pasien akan terasa dingin apabila disentuh.

Pada penelitian ini, rata-rata suhu tubuh pasien hari ke-4 dan ke-5 demam mengalami penurunan yang menandakan terjadinya fase kritis pada pasien DF/DHF, yakni berkisar $37,4{ }^{\circ} \mathrm{C}$ dan $37,2{ }^{\circ} \mathrm{C}$ pada pasien kelompok pengguna cairan standar $\mathrm{WHO}$, dan berkisar $37,2^{\circ} \mathrm{C}$ dan $36,8^{\circ} \mathrm{C}$ pada pasien kelompok cairan inisial. Menurut WHO (2011), pasien yang dapat bertahan setelah 24 hingga 48 jam masa kritis akan mengalami reabsorbsi cairan kompartemen ekstravaskuler secara bertahap dalam 48 hingga 72 jam yang ditandai dengan stabilnya status hemodinamik. Hal tersebut didukung oleh hasil mean \pm SD suhu badan saat memasuki fase pemulihan, yakni demam hari ke-6 sampai ke-8, menunjukkan bebas demam pada penggunaan terapi cairan inisial dan terapi cairan standar WHO, walaupun secara statistik tidak terdapat perbedaan yang signifikan $(\mathrm{p}>0,05)$.

Pada DBD, terjadinya infeksi virus dengue akan merangsang terjadinya respon tubuh imun spesifik yang lalu membentuk ikatan (kompleks) dengan virus. Ikatan ini akan mengaktifkan komplemen seperti mediator C3a dan C5a yang memengaruhi sel endotel vaskuler dan menimbulkan perembesan plasma. ${ }^{12}$ Terjadinya kebocoran plasma ke ruang ekstravaskular akan mengakibatkan terjadinya peningkatan nilai hematokrit. ${ }^{4}$ Hemokonsentrasi akibat perembesan plasma dapat ditentukan berdasarkan peningkatan nilai hematokrit. Salah satu tanda/bukti awal peningkatan hematokrit yakni nilai berada sebesar $10-15 \%$ di atas baseline. ${ }^{4}$ Menurut WHO (2011), jika pasien selamat pada 24-48 jam di fase kritisnya, akan terjadi reabsorbsi cairan ekstravaskular selama 48-72 jam. 
Hal tersebut sejalan dengan hasil penelitian ini: nilai maksimal hematokrit yang diperoleh setelah 72 jam mendapatkan terapi cairan menunjukkan bahwa nilai hematokrit pasien kelompok penggunaan terapi cairan inisial (39\%) menurun lebih cepat dibandingkan dengan kelompok penggunaan terapi cairan standar WHO (48\%) walaupun tidak berbeda secara signifikan $(p>0,05)$. Nilai hematokrit kembali stabil saat memasuki fase pemulihan pada demam hari ke-7 dan 8 dengan nilai hematokrit pasien kelompok cairan standar WHO yaitu $36,1 \%$ dan $35,5 \%$, dan kelompok cairan inisial sebesar $37,5 \%$ dan $38,2 \%$.

Berdasarkan penelitian ini, pasien mampu melewati masa kritis dan terdapat perbedaan yang signifikan $(p<0,05)$ antara kelompok penggunaan terapi cairan inisial dan terapi cairan standar WHO terhadap perubahan ratarata peningkatan trombosit selama pasien dirawat. Hasil penelitian yang dilakukan oleh Sari et al. (2017) pada pasien DHF dengan disertai syok memperoleh rata-rata trombosit $52,382 \mathrm{sel} / \mathrm{mm}^{3}$ yang terjadi pada hari ke-3 demam dan peningkatan trombosit terjadi pada hari ke-7 demam. ${ }^{13}$ Masa viremia hanya berlangsung selama 5-7 hari. Jika pasien mampu melewati masa kritis, setelah 48-72 jam dari masa kritis, cairan ekstravasasi akan masuk kembali ke dalam intravaskular dan jumlah trombosit pasien secara alami akan meningkat hingga lebih dari $150.000 / \mu \mathrm{L}$ dalam waktu 2-3 hari setelah masa kritis ${ }^{4}$.

Secara umum, lama perjalanan penyakit DBD adalah 7-10 hari. Selama pengambilan sampel, rata-rata keluarga pasien membawa anaknya ke rumah sakit untuk melakukan pengobatan minimal pada hari ke-3 demam dan maksimal di hari ke-5 demam. Hal ini diperkuat dengan rata-rata lama rawat inap pasien DBD yang diperoleh pada penelitian ini, yakni 4,48 hari. Hasil yang serupa juga ditemukan pada penelitian oleh Divy et al. (2018) di RSUP Sanglah yang memperoleh hasil rata-rata lama rawat inap pasien DBD yakni 4,3 hari. ${ }^{14}$

Terdapat beberapa keterbatasan pada penelitian ini, salah satunya pasien DF/DHF dianggap sama dari segi tingkat keparahannya (grade I, II, III, IV). Selain itu, jumlah sampel penelitian ini pun terbatas. Oleh karena itu, untuk mendapatkan sampel minimum yang lebih banyak, diperlukan peningkatan power penelitian. ${ }^{15}$

\section{Simpulan}

Efektivitas terapi cairan standar WHO dan terapi cairan inisial secara statistik tidak menunjukkan perbedaan bermakna terhadap perbaikan klinis (suhu badan) dan nilai hematokrit $(p>0,05)$; dan menunjukkan perbedaan bermakna terhadap peningkatan trombosit dan penurunan lama rawat inap $(\mathrm{p}<0,05)$.

\section{Ucapan Terima Kasih}

Terima kasih kepada segenap tim peneliti (dokter jaga IGD, apoteker, perawat) dan pegawai staf RS PKU Muhammadiyah PKU Bantul Yogyakarta yang telah membantu dalam pengambilan data penelitian.

\section{Pendanaan}

Penelitian ini tidak didanai oleh sumber hibah manapun.

\section{Konflik Kepentingan}

Seluruh penulis menyatakan tidak terdapat potensi konflik kepentingan dengan penelitian, kepenulisan (authorship), dan atau publikasi artikel ini.

\section{Daftar Pustaka}

1. Candra A. Demam berdarah dengue: Epidemiologi, patogenesis, dan faktor 
risiko penularan. Aspirator. 2010;2(2): 110-9.

2. Kementerian Kesehatan Republik Indonesia. Situasi DBD di Indonesia [diunduh November 2017]. Tersedia dari: http:// www.depkes.go.id/resources/download/ pusdatin /info datin/infodatindbd2016

3. Chen K, Pohan HT, Sinto R. Diagnosis dan terapi cairan pada demam berdarah dengue. Medicinus. 2009;22(1):3-7.

4. World Health Organization. Comprehensive guidelines for prevention and control of dengue and dengue haemorrhagic fever. India: WHO Press; 2011.

5. Cahyani M, Tjeng WS, Khotimat S. Hubungan antara peningkatan nilai hematokrit, derajat trombositopenia, dan status gizi lebih dengan kejadian syok pada pasien demam berdarah dengue anak di RSUD Abdul Wai-Iab Sjahranie Samarinda. J Kedokt Mulawarman. 2018; 4(1):21-8.

6. Setiawati S. Analisis faktor-faktor risiko terjadinya dengue syok sindrom (DSS) pada anak dengan demam berdarah dengue (DBD) di RSUP Persahabatan dan RSUD Budhi Asih (tesis). Jakarta: Universitas Indonesia; 2011.

7. Zumaroh. Evaluasi pelaksanaan surveilans kasus demam berdarah dengue di Puskesmas Putat Jaya berdasarkan atribut surveilans. Epidemilogi. 2015;3(1):82-94.

8. Kulkarni MJ, Sarathi V, Bhalla V, Shivpuri D, Acharya U. Clinico-epidemiological profile of children hospitalized with dengue. Indian J Pediatr. 2010;7:1103-7. doi: 10.1007/s12098-010-0202-2.
9. Syahribulan, Biu FM, Hassan MS. Waktu aktivitas menghisap darah nyamuk Aedes aegypti dan Aedes albopictus di Desa Pa'lanassang Kelurahan Barombong Makassar Sulawesi Selatan. J Ekologi Kesehatan. 2012;11(4):306-14.

10. Pranata IWA, I Gusti AA. Gambaran pola penatalaksanaan demam berdarah dengue (DBD) pada anak di instalasi rawat inap Rumah Sakit Umum Daerah Kabupaten Buleleng tahun 2013. E-Jurnal Medika. 2017;6(5):21-7.

11. Nugraha J, Widijatmoko TE. Peran antigen Ns1 dengue terhadap penghitungan trombosit dan penampakan (manifestasi) klinis penjangkitan/penularan (infeksi) virus dengue. Indones J Clin Pathol Med Laboratory. 2010;16(3):110-7. doi: 10.242 93/ijcpml.v16i3.1038

12. Sudjana P. Diagnosis dini penderita demam berdarah dengue dewasa. Buletin Jendela Epidemiologi. 2010;2:21-5.

13. Sari RC, Kahar H, Puspitasari D. Pola jumlah trombosit pasien infeksi virus dengue yang dirawat di SMF Ilmu Kesehatan Anak RSUD Dr. Soetomo Surabaya. Sari Pediatri. 2017;19(1):1-6. doi: 10.14238/sp19.1.2017.1-6

14. Divy NPA, Sudarmaja IM, Swastika IK. Karakteristik penderita demam berdarah dengue (DBD) di RSUP Sanglah Bulan Juli-Desember tahun 2014. E-Jurnal Medika. 2018;7(7):1-7.

15. Sastroasmoro S, Ismael S. Dasar-dasar metodologi penelitian klinis, edisi ke-5. Jakarta: Sagung Seto; 2014. 